\title{
LARGE SCALE PROCESSES FOR UNDERSTANDING EXTREME RAIN STORM OVER RANGAMATI ON 12 JUNE 2017-A CASE STUDY
}

\author{
Samarendra Karmakar ${ }^{1,2}$, Mohan Kumar Das ${ }^{1,3^{*}}$ and Haripada Sarker ${ }^{4}$ \\ ${ }^{I}$ National Oceanographic and maritime Institute, Dhaka, Bangladesh \\ ${ }^{2}$ Former Director, Bangladesh Meteorological Department, Dhaka, Bangladesh \\ ${ }^{3}$ Institute of Water and Flood Management, BUET, Dhaka, Bangladesh \\ ${ }^{4}$ Jahangirnagar University, Savar, Bangladesh
}

Received: 03 November 2020

Accepted: 01 December 2020

\begin{abstract}
Attempts have been made to study the large-scale surface and upper air synoptic processes associated with a monsoon depression during 11-12 June 2017. In this study, Grid Analysis and Display System (GrADS) software has been used to prepare the large-scale sea level pressure and upper flow patterns by analyzing the FNL re-analysis data. In this analysis, FNL dataset is used to characterize the rainstorms, with key hydrometeorological variables describing the prior conditions of the very heavy rainfall event presented the study. National Center for Environmental Prediction (NCEP) Final (FNL) analysis data of $1^{\circ}$ by $1^{\circ}$ grids for every 6 hours are used for large scale synoptic analysis. The disastrous event was a strong monsoon depression in the early period of southwest monsoon 2017. Due to this depression, very heavy rainfall occurred in the southeastern Bangladesh. Rangamati recorded $343 \mathrm{~mm}$ of rainfall in the 24 hours on 12 June 2017. Massive landslides occurred in three districts such as Rangamati, Bandarban and Chittagong. The analysis of surface and upper air synoptic conditions has revealed that a well-marked low was formed over the northwest Bay of Bengal within the low-pressure belt passing from Somalia coast extending through southern Pakistan, and India up to east central Bay of Bengal and adjoining Bangladesh. The wind speed is calculated from the pressure distribution and is found to be $24.23 \mathrm{~ms}^{-1}$, which is at par with the observed one. The well-marked low was subsequently intensified into a depression and moved northeastwards over Bangladesh. Strong southsouthwesterly winds were associated in the eastern side of the depression, especially over Chittagong Hill Tracts. The depression was found to extend up to $500 \mathrm{hPa}$ level as seen from the distribution of geopotential and strong circulation around the centre. Winds were advecting from large continental and Ocean areas over the South Asia. Strong winds and moisture influx, strong narrow coma-like trough from a micro low at the surface to $500 \mathrm{hPa}$ level as well as strong wind shear were responsible for the heavy rainfall, disastrous effects and massive landslides over Rangamati and adjoining areas.
\end{abstract}

Key words: Large scale; coma-like trough; heavy rainfall; geopotential; anticyclone; circulation.

\section{INTRODUCTION}

The southwest monsoon of South Asia is characterized with onset/withdrawal dates, active rainfall regimes, active/break phases and frequent synoptic disturbances, especially at the surface. The annual cycle of solar radiation interacting with different heat capacities of the tropical ocean and land areas provides the basic forcing of the monsoon of this region ( $\mathrm{Li}$ and Yanai, 1996). The monsoon flow is giant sea breeze circulation and is a part of the global circulation. During the pre-monsoon season, strong heating develops an intense thermal low over northern Indian sub-continent before the onset of southwesterly flow of monsoon. This thermal low is known as 'Heat low'.

The evolution, advancement with active/break or stagnation aspects and retreat are the most important periods associated with of southwest monsoon over India, Bangladesh and adjoining areas as they essentially decide the duration of the summer monsoon and the quantity of rainfall over different parts of India and Bangladesh. The arrival of the southwest monsoon over India and Bangladesh is also important, occurring towards the end of May or in early June over the southern tip of the Indian (Kerala) coast and Bangladesh. Identification of the date of onset over the Kerala coast and southeastern coast of Bangladesh is based on a sharp increase and characteristic persistency of the rainfall (Ananthakrishnan et al., 1968; Ahmed and Karmakar, 1993). According to Ahmed and Karmakar (1993), the normal onset date of southwest monsoon over southeastern Bangladesh is 2 June with standard deviations of 7-10 days and the normal date of withdrawal of monsoon from the northwestern part of Bangladesh is 30 September. During this period, the strength of overall monsoon in a particular year, forecasting of the onset date and active and break phases are significantly related to the economy and livelihoods of the people of Bangladesh. Late or early onset of monsoon, its active and break periods have 
significant impact on the rainfall over the country; heavy to very heavy rainfall over the catchment areas causes devastating floods in Bangladesh and over the eastern part of the country causes devastating landslides, flash floods, water logging over Chittagong, Cox's Bazar, Chittagong Hill Tracts and Sylhet region. These disastrous events kill a number of people, livestock, damage houses, properties, agricultural crops, etc.

It is well recognized that the onset of the summer monsoon is accompanied by distinct changes in the large-scale circulation and rainfall distribution over the landmass of India and Bangladesh and surrounding oceanic regions. During the southwest monsoon season, the winds at lower levels from the southern hemisphere cross the equator off the Somali coast and turn towards the Indian Peninsula with an average speed of around $15 \mathrm{~ms}^{-1}$ and this wind is called the Low-Level Jet (LLJ) stream (Joseph and Raman, 1966). The strength of the LLJ increases from June to August and thereafter it decreases. A number of studies in this regard have been made by many scientists such as Koteswaram (1958), Findlater (1969), Krishnamurti and Ramanathan (1982), Mohanty et al. (1983), Pearce and Mohanty (1984), Rao and Aksakal (1994), Ananthakrishnan and Soman $(1988,1989)$ and Soman and Krishnakumar (1993). In a study, Raju et al. (2005) found that the strength of the low-level Somali jet and upper tropospheric tropical easterly jet increase rapidly during the advancement of the summer monsoon over India. Predominant changes are noticed in the large-scale balances of kinetic energy, heat and moisture over the Bay of Bengal and the Arabian Sea, from the pre-onset to the post-onset periods. A zone of flux convergence of heat and moisture is noticed over the eastern sector of the Bay of Bengal before the onset of the summer monsoon over India. During onset of monsoon, the horizontal flux convergence of heat and moisture, as well as diabatic heating, are enhanced over the Arabian Sea. These subsequently increase with the evolution and advancement of the monsoon over India.

Chowdhury and Karmakar (1980a) studied the energetic of the troposphere over the Arabian Sea with advancement of south-west monsoon and found that all the components of tropospheric energy increase over the Arabian sea with the advancement of southwest monsoon and the increase is mainly due to the contribution of latent heat energy. This increase in energy takes place because of the strengthening of the westerly and southerly wind components and their vertical extension in the upper troposphere (Chowdhury and Karmakar, 1980b).

Murakami and Ding (1982) compared the large-scale circulation and temperature fields before and after the onset of Indian summer monsoon in 1979. They found that the maximum warming took place over the Afghanistan-western Tibetan plateau region and over the east China Sea-Japan region. They emphasized the importance of diabatic heating over the Eurasian continent as a whole in establishing the summer monsoon circulation. Hsu et al. (1999) elucidated the changes in circulation and heating associated with the first transition of the Asian summer monsoon. The significant features include the development of a low-level cyclonic circulation and an upper level anticyclone in south Asia, as well as strong convection in the Bay of Bengal.

The present study has been undertaken to investigate the large-scale processes associated with very heavy rainfall over Rangamati occurred on 12 June 2017. The study includes the synoptic and upper air conditions responsible for the occurrence of very heavy rainfall over Rangamati during the early phase of southwest monsoon in Bangladesh in 2017. Rangamati is located in the Chittagong Division as shown in Figure 1. It is bordered by the Tripura state of India to the north, Bandarban district to the south, Mizoram State of India and Chin State of Myanmar to the east, and Khagrachari and Chittagong Districts to the west. Rangamati is the only district in Bangladesh with international borders with two countries: India and Myanmar. The area of the district is $6116 \mathrm{~km}^{2}$ of which $1292 \mathrm{~km}^{2}$ is riverine and $4825 \mathrm{~km}^{2}$ is under forest vegetation.

\subsection{Description of the depression}

A low-pressure was formed over West-Central and adjoining North Bay of Bengal off Andhra-Odisha coasts in the afternoon on 9 June 2017. The low is seen in satellite imagery (Figure 2). It then intensified into a wellmarked low over West-central Bay and adjoining North Bay at 0000 UTC on 10 June 2017. The well-marked low pressure over west central Bay and adjoining North Bay lies also over northwest Bay of Bengal and adjoining area on 11 June 2017. The synoptic chart is showing the position of the well-marked low and the large-scale surface synoptic condition over the Bay of Bengal, Bangladesh, India and adjoining countries (Figure 3a). On 12 June 2017, it moved northeastwards, intensified into a depression over northwest Bay of Bengal with a trough extended northeastwards; it further moved northeastwards and lay as a land depression over Bhola and adjoining area at 0000 UTC on 12 June 2017 (Figure 3b). The depression subsequently moved northeastwards further over Bangladesh and centered over Cumilla and adjoining area at 0600 UTC on the same day (Figure 3c). Extremely highest steep pressure gradient exists over Chittagong Hill Tracts, the eastern side of the land depression and this steep gradient is the cause of high wind speed the area, causing significant damages to properties and natural resources. Due to the strong wind speed \& circulation, convergence of wind at the depression center, steep pressure gradient, the system is laden with heavy moisture, which due to orographic effect has caused very heavy downpour over the eastern side of the land depression. This very heavy downpour 
has been the root of massive landslides in three hilly districts. The land depression then moved more northeastwards over Bangladesh and weakened becoming unimportant (BMD-Report 2017).

Under the influence of the depression over Bangladesh and due to steep pressure gradient, heavy rainfall occurred over southeast part of Bangladesh on 12 June 2017. The spatial distribution of rainfall over Bangladesh is shown in Figure 3d. Depression originated at northwest Bay of Bengal and adjacent areas causes extreme rainfall in the coastal regions on June 12, 2017 and triggered massive landslides in three districts of southeast Bangladesh i.e. Rangamati, Bandarban and Chittagong. About 132 people including several rescuers (officers and members of the army) have been killed by these landslides in these three districts. Many people were hurt and many remained missing. Rescue operations were delayed due to bad weather, but were continuing with difficulties.

Chittagong alone experienced $222 \mathrm{~mm}$ of rain during the same period. As a result, much of the low-lying areas of the hilly districts went under water. As well, this torrential rainfall triggered massive landslides in three districts of southeast Bangladesh i.e. Rangamati, Bandarban and Chittagong. These landslides killed many people who remained in their shanty-like homes at the foot of the hills risking their lives, despite warnings by the local administrations (Relief web, 2017)

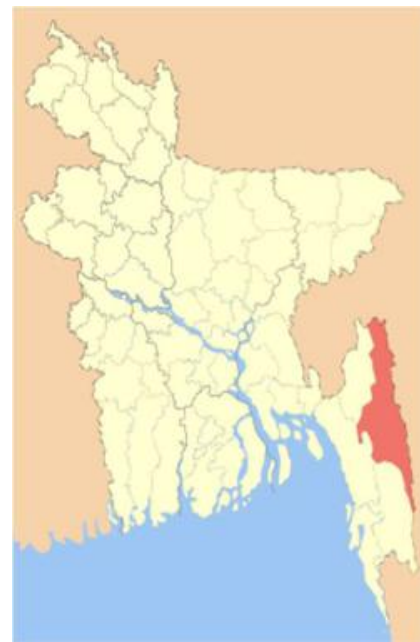

Figure 1: Location of Rangamati district (red colour) in Bangladesh

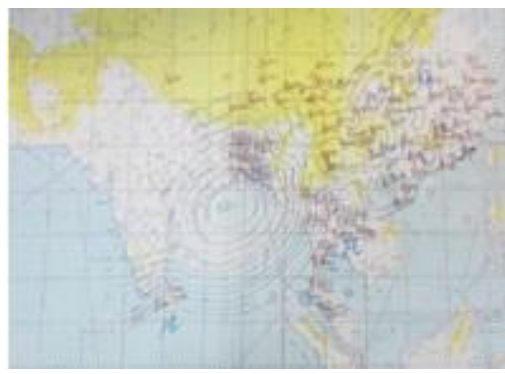

(a)

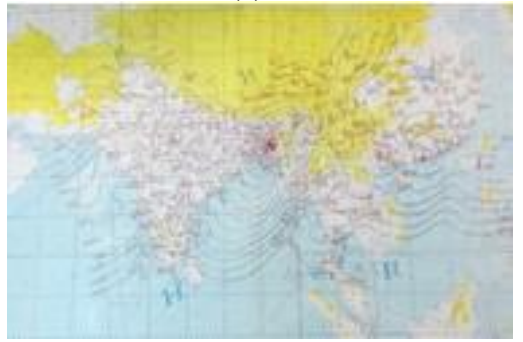

(c)

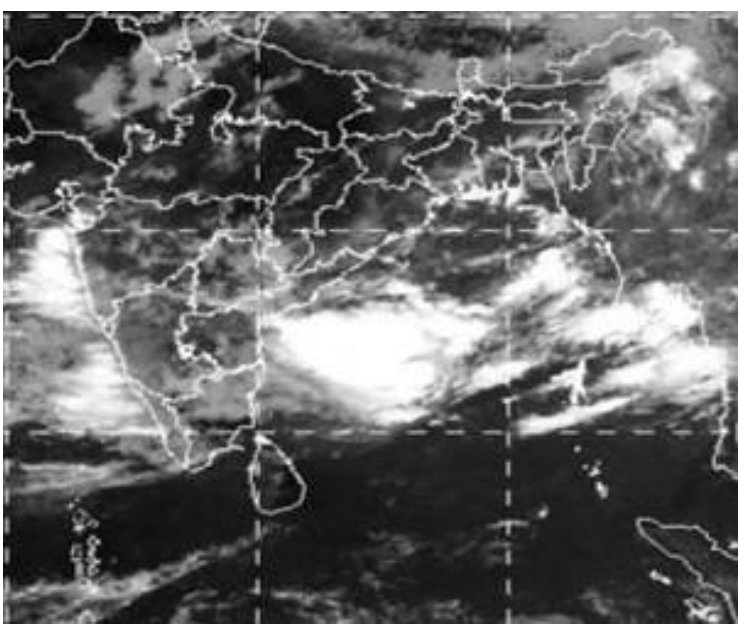

Figure 2: Satellite image taken on June 9, 2017 at 08.15 IST Image (source: IMD)

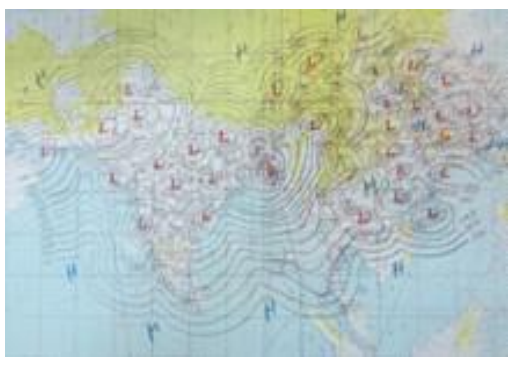

(b)

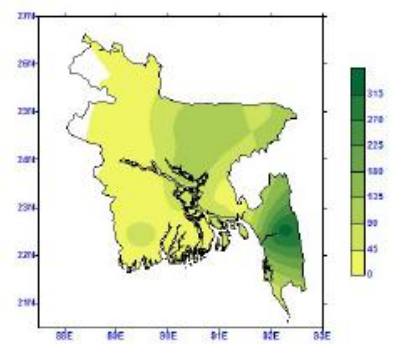

(d)

Figure 3: Surface synoptic condition at (a) 0000UTC on 11 June 2017, (b) 0000UTC on 12 June 2017, (c) 0600UTC on 12 June 2017 and (d) Spatial distribution of 24 hours rainfall over Bangladesh on 12 June 2017 


\subsection{Data used}

In this research, National Center for Environmental Prediction (NCEP) Final (FNL) analysis data of $1^{\circ}$ by $1^{\circ}$ grids for every 6 hours are used (NCEP FNL; hereafter, FNL) for large scale synoptic analysis. The FNL product is generated from the Global Data Assimilation System (GDAS). GDAS is a continuous collection of observational data through GTS and different sources. In the FNL products, analyses are presented from 1000 to $10 \mathrm{hPa}$. The common parameters are surface pressure, sea level pressure, geopotential height, temperature, sea surface temperature, soil values, ice cover, relative humidity, u- and v- winds, vertical motion, vorticity and ozone. In addition, three hourly synoptic observations and synoptic charts of Bangladesh Meteorological Department (BMD) are analyzed in this study for understating the extreme rainstorm event over Rangamati and adjoining areas.

\subsection{Methodology}

The large-scale sea level pressure and upper flow patterns have been prepared by analyzing the FNL re-analysis data with the help of software GrADS. In this analysis, FNL dataset is used to characterize the rainstorms, with key hydro-meteorological variables describing the prior conditions of the very heavy rainfall event presented the study. The outputs have helped to investigate the synoptic and environmental characteristics of the depression which affected Rangamati severely causing landslides and damaging infrastructures along with the loss of agricultural crops and human lives. The distribution of sea level pressure, geopotential and wind flows at different constant pressure levels and different synoptic hours along with the synoptic charts obtained from BMD have been investigated during 11-12 June 2017.

\section{RESULTS AND DISCUSSION}

\subsection{Large scale distribution of sea level pressure and winds at $10 \mathrm{~m}$}

Sea level pressure and wind vectors at $10 \mathrm{~m}$ height on 11 June 2017 at 0000 UTC over Bangladesh, India and adjoining areas are shown in Figure 4. The figure shows a belt of low pressure system from Somalia coast extending through southern Pakistan, and India up to east central Bay of Bengal and adjoining Bangladesh. The minimum pressure of about $995 \mathrm{hPa}$ is found over Northwest Bay and indicates the centre of the well-marked low. Except the centre of the well-marked low, the range of pressure over is $999 \mathrm{hPa}$ to $1003 \mathrm{hPa}$ along the lowpressure belt. In the south and east (Eastern Asia) of the low-pressure belt, the sea level pressure ranges from $1004 \mathrm{hPa}$ over the Arabian Sea (AS) and Bay of Bengal (BoB) to more than $1010 \mathrm{hPa}$ over the South Indian Ocean. The range of $1010 \mathrm{hPa}$ to $1021 \mathrm{hPa}$ pressure exists in Tibetan Plateau and adjoining areas. The existence of the low-pressure belt over Somalia-Pakistan-India-Bangladesh and North BoB is responsible to bring strong southwesterly winds over the AS and the BoB, intensifying the southwest monsoon over South Asia and converging the winds into the well-marked low as well as over the low-pressure belt.

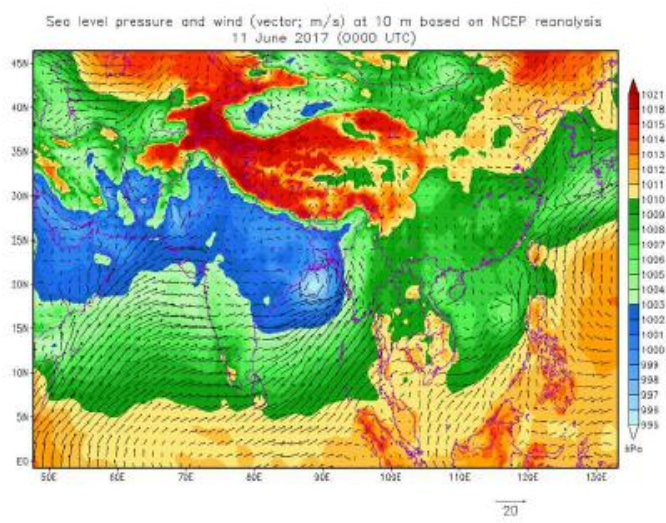

Figure 4: Large scale distribution of sea level pressure and winds at 10-meter level at 0000 UTC on 11 June 2017

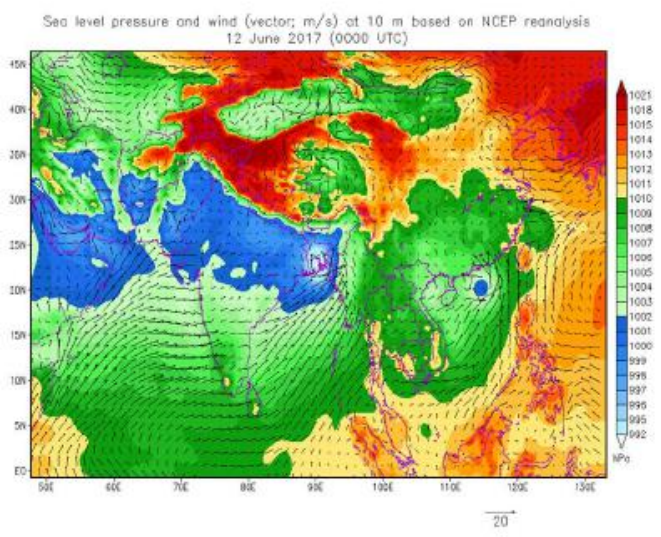

Figure 5: Large scale distribution of sea level pressure and winds at 10-meter level at 0000 UTC on 12 June 2017

The winds at $10 \mathrm{~m}$ from the southern hemisphere are found to cross equator off the Somali coast and deflected towards the Indian Peninsula with increased speed. At 0000 UTC on 11 June 2017, the maximum wind speed 
$>20 \mathrm{~ms}^{-1}$ was seen in AS and BoB. Near the centre of the well-marked low, the pressure is about $995 \mathrm{hPa}$ with a pressure drop of about $4 \mathrm{hPa}$ and the wind speed is about $10 \mathrm{~ms}^{-1}$ but at its eastern periphery near Rangamati, the wind is south-southeasterly with higher speed near $15-20 \mathrm{~ms}^{-1}$ (Figure 4). This wind speed is due to steep pressure gradient and is relatively high indicating a more intense system. The wind speed except is small over Bangladesh, India, Myanmar and Tibetan Plateau.

In Figure 5 on 12 June 2017 at 0000 UTC, the well-marked low is seen to intensify into a depression, moved northeastwards over Bhola, with a strong trough extended to northeastern part of Bangladesh. In this position the central pressure of the depression was less than $990 \mathrm{hPa}$ with a pressure drop of about $11 \mathrm{hPa}$. This pressure drops, according to the modified Fletcher's formula (Mishra and Gupta, 1976) $V_{\max }=14.2 \sqrt{P_{o}-P_{c}}$ is about $47.1 \mathrm{kts}\left(24.23 \mathrm{~ms}^{-1}\right)$. Here $\left(\mathrm{P}_{\mathrm{O}}-\mathrm{P}_{\mathrm{c}}\right)$ is in $\mathrm{hPa}, \mathrm{P}_{\mathrm{O}}$ is the peripheral pressure, $\mathrm{P}_{\mathrm{c}}$ is the central pressure and $\mathrm{V}_{\max }$ is in knots. At the eastern periphery of the depression over Rangamati, the wind speed is $>20 \mathrm{~ms}^{-1}$, the wind being directly from the south. This wind speed is very near to the value obtained as above and was responsible for the destruction of dwelling houses.

At that time, the pressure in northern part of India, western part of Pakistan, western part of Arabian Sea and adjacent area was $999 \mathrm{hPa}$ to $1002 \mathrm{hPa}$. During this time, the pressure range of $1002 \mathrm{hPa}$ to $1010 \mathrm{hPa}$ is seen over the southern part of BoB, South India, middle and southern region of the AS, Myanmar and its eastern part, eastern and northern parts of India and some portion of Tibetan Plateau and the pressure of 1010 to $1021 \mathrm{hPa}$ is found in the western part of Tibetan Plateau. At 0000 UTC on 12 June 2017, the low-level jet with wind speed $>20 \mathrm{~ms}^{-1}$ is found to exist over the AS and BoB. Over the region, the wind speed is $<20 \mathrm{~ms}^{-1}$.
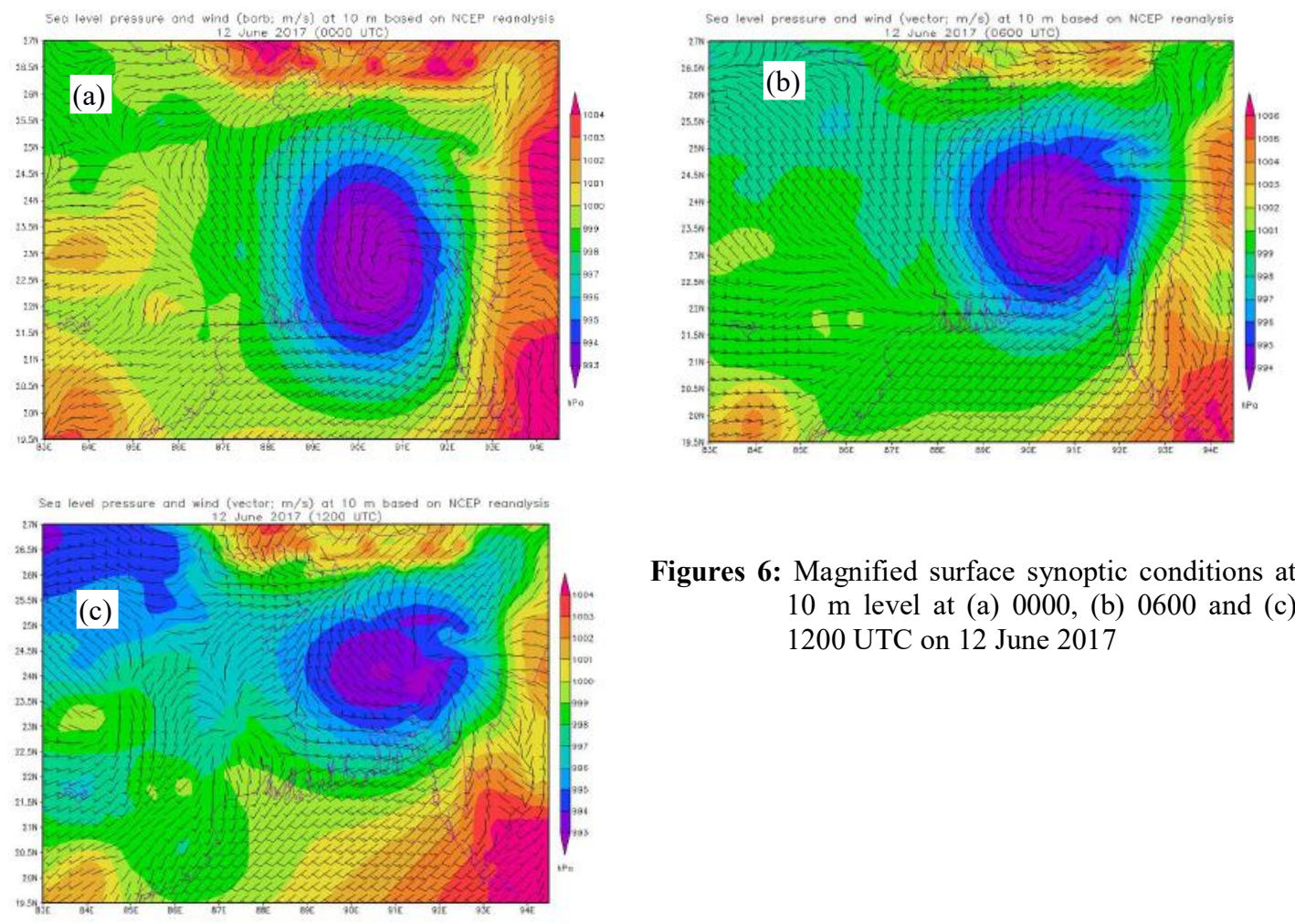

Figures 6: Magnified surface synoptic conditions at $10 \mathrm{~m}$ level at (a) 0000, (b) 0600 and (c) 1200 UTC on 12 June 2017

The surface synoptic conditions are also studied by magnifying the synoptic charts for specifying clear pressure distributions, the centre and circulation patterns of the depression and are shown in Figures 6(a-c) for 0000, 0600 and 1200 UTC on 12 June 2017 respectively. A trough of low is extended over Rangamati region. Figure $6 \mathrm{a}$ indicates the center of the depression at 0000 UTC over northern Bhola and adjoining area with lowest pressure of $992 \mathrm{hPa}$. Strong circulation of winds exists surrounding the depression, having the significant onrush of wind flows from large surrounding land and ocean areas. The southwesterly winds of $20 \mathrm{~ms}^{-1}$ are found in the south of the depression centre and south-southeasterly wind of 5-15 $\mathrm{ms}^{-1}$ over the eastern end of the depression i.e. Chittagong Hill tracts. At 0600 UTC, the depression is found to move over Cumilla with intense trough extended over Rangamati region and the same circulation pattern exists there (Figure 6b). The depression is found to disintegrate into two parts: one over Cumilla and another over Agartala at 1200 UTC, having extended trough eastwards covering Rangamati region too. But the circulation exists over the Agartala region (Figure 6c). It is, therefore, evident that the extended trough from the centre of the depression and the strong wind 
circulation from the large continental and oceanic areas are the causes for very heavy rainfall and widespread damages over Rangamati region.

\subsection{Large scale distribution of winds and geopotential height at $950 \mathrm{hPa}$}

The circulation is found to extend vertically to $950 \mathrm{hPa}$ levels for $0000 \mathrm{UTC}$ on 11 and 12 June 2017. Southwesterly winds are also strong at $950 \mathrm{hPa}$ level over the $\mathrm{BoB}$ and the coastal region of the country. The strong southwesterly winds and the circulation with its vertical extension confirm the strong influx of moisture over Bangladesh and adjoining area. The distribution of geopotential height and winds at $950 \mathrm{hPa}$ level on at 0000 UTC 11 June 2017 over Bangladesh and adjoining area are shown in Figure 7a. A low geopotential height is found over northwest BoB with minimum value of 430 to $440 \mathrm{~m}$. Relatively lower geopotential height of 450$470 \mathrm{~m}$ exists over northern India and Bangladesh. The geopotential height of 470 to $510 \mathrm{~m}$ is found in the southern BoB, Myanmar and Arabian Sea. There exists a strong southwesterly flow of winds from the BoB converging at the centre of the low geopotential height over the northwest $\mathrm{BoB}$ and adjoining area. These winds are cross-equatorial flows from the southern hemisphere coming over the AS. The wind speed over the BoB is more than $20 \mathrm{~ms}^{-1}$ and about $20 \mathrm{~ms}^{-1}$ in the eastern periphery of the low. The wind speed of $5-10 \mathrm{~ms}^{-1}$ exists in northern part of Bangladesh and northern India.
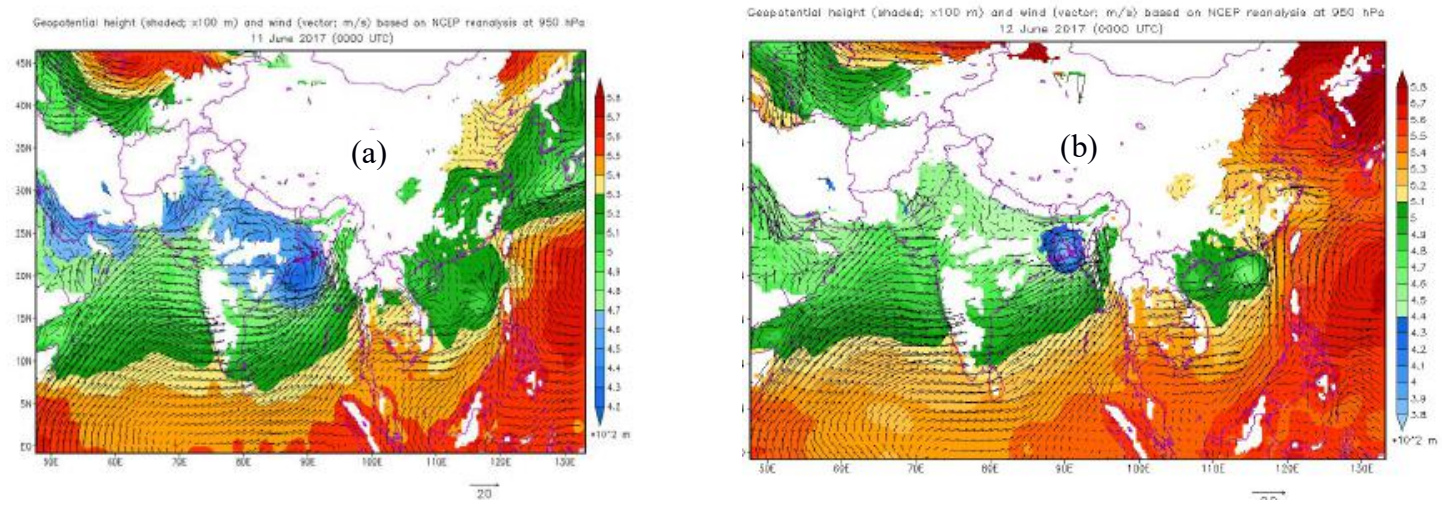

Figure 7: Large scale distribution of geopotential height and winds (a) at $950 \mathrm{hPa}$ at $0000 \mathrm{UTC}$ on 11 June 2017 (b)at $950 \mathrm{hPa}$ at $0000 \mathrm{UTC}$ on 12 June 2017
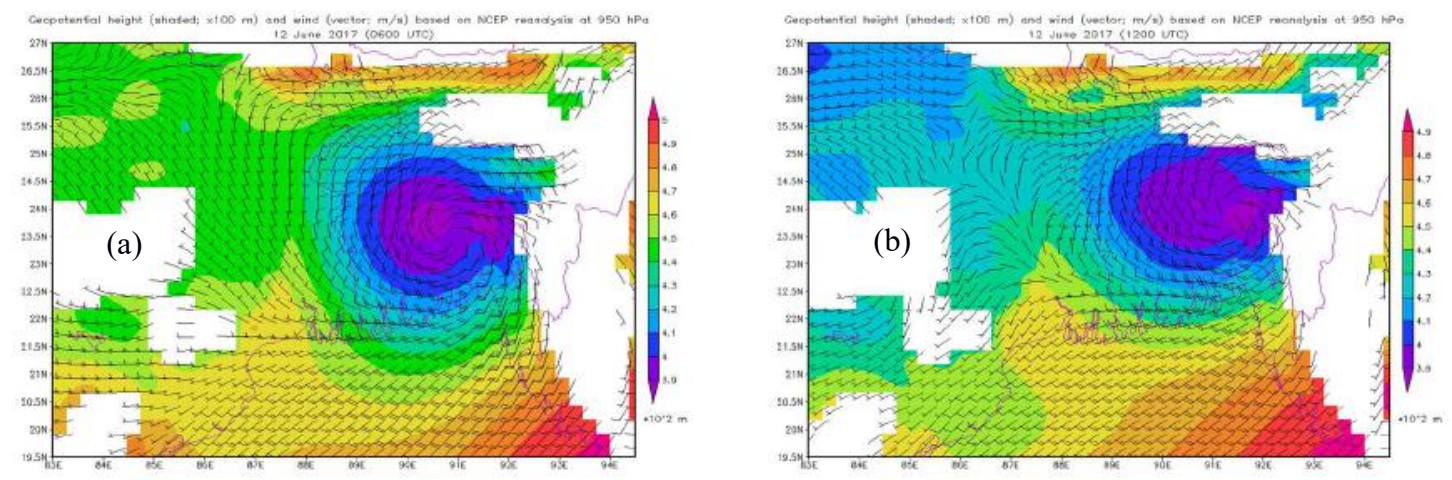

Figure 8: Magnified synoptic conditions at $950 \mathrm{hPa}$ level of (a) 0600 and (b) 1200 UTC on 12 June 2017

At $950 \mathrm{hPa}$ level, the distributions of geopotential height and winds at 0000 UTC on 12 June 2017 over Bangladesh and adjoining area are shown in Figure 10. The figure shows that there is low geopotential height shifted over Bhola and adjoining area with minimum geopotential height $370 \mathrm{~m}$ at the centre. Relatively lower geopotential height of 440 to $460 \mathrm{~m}$ exists over Northern India and northern Bangladesh. The maximum geopotential height of 460 to $500 \mathrm{~m}$ is found in the northern BoB and Arabian Sea.

There exists a strong southwesterly flow of winds from the Somalia coast passing through the AS, southern continental area of India and the BoB converging into the low geopotential centre. The wind speed is more or less the same as that on 11 June 2017 except that the circulation over the low geopotential area has become stronger with strong winds more than $20 \mathrm{~ms}^{-1}$ over Chittagong Hill Tracts. It is interesting to note that there is a crossing of southwesterly strong wing and southeasterly stronger flow near the Rangamati area (Figure 7b), 
which is responsible for the widespread damage of houses and natural resources. In the northern side of Bangladesh and India, wind is lower.

The magnified synoptic conditions at $950 \mathrm{hPa}$ for 0600 and 1200 UTC are shown in Figures 8(a-b) respectively. The depression centre has low geopotential height of $380 \mathrm{~m}$ over Cumilla and adjoining area and a separate micro-cell of low geopotential height is formed in the extended trough over Rangamati region at 0600 UTC. There is intense circulation over eastern Cumilla and Rangamati with stronger wind speed than that at $10 \mathrm{~m}$ level. The winds are advected into the centre of the depression from large continental and ocean areas (Figure 8a). At $1200 \mathrm{UTC}$, the micro-cell of low geopotential height at $950 \mathrm{hPa}$ over Rangamati region has become prominent with narrow trough extended to north Rangamati (Figure 8b). The circulation is almost the same coming from the continental and ocean areas. Wind speed of $10-15 \mathrm{~ms}^{-1}$ exists over Rangamati and southwesterly winds of $20-25 \mathrm{~ms}^{-1}$ exist at $950 \mathrm{hPa}$ level at 0600 UTC on 12 June over southern part of the depression and the BoB. This higher wind has been responsible for significant moisture influx over Rangamati region.

\subsection{Large scale distribution of winds and geopotential height at $850 \mathrm{hPa}$}

The circulation is found to extend vertically to $850 \mathrm{hPa}$ levels at $0000 \mathrm{UTC}$ on 11 and 12 June 2017. A strong circulation of winds exists at $850 \mathrm{hPa}$ level over the northwest $\mathrm{BoB}$ and adjoining southwestern coast of Bangladesh at 0000 UTC on 11 June 2017 as seen in Figure 9 a. Winds of speed $<20 \mathrm{~ms}^{-1}$ are found to converge over the centre of the well-marked low. Wind speed of about $15 \mathrm{~ms}^{-1}$ is found to exist over Rangamati region as evident from the analysis of magnified chart (not shown here). The winds are coming from all sides, having lower speed in the north and northwestern parts of the country. There exists a strong southwesterly flow of winds from the $\mathrm{BoB}$ converging at the centre of the low geopotential height over the northwest $\mathrm{BoB}$ and adjoining area. These winds are cross-equatorial flows from the southern hemisphere coming over the AS. The figure also shows the distribution geopotential height at $850 \mathrm{hPa}$ at $0000 \mathrm{UTC}$ on 11 June 2017. At that time the low geopotential height of $1400 \mathrm{~m}$ lays at the centre of wind circulation over northwest BoB. There is a relatively low geopotential height over Pakistan, India, AS, central BoB extended to northeast over China with the embedded minimum low geopotential height over the northwest BoB. Beyond this region, the geopotential is higher.
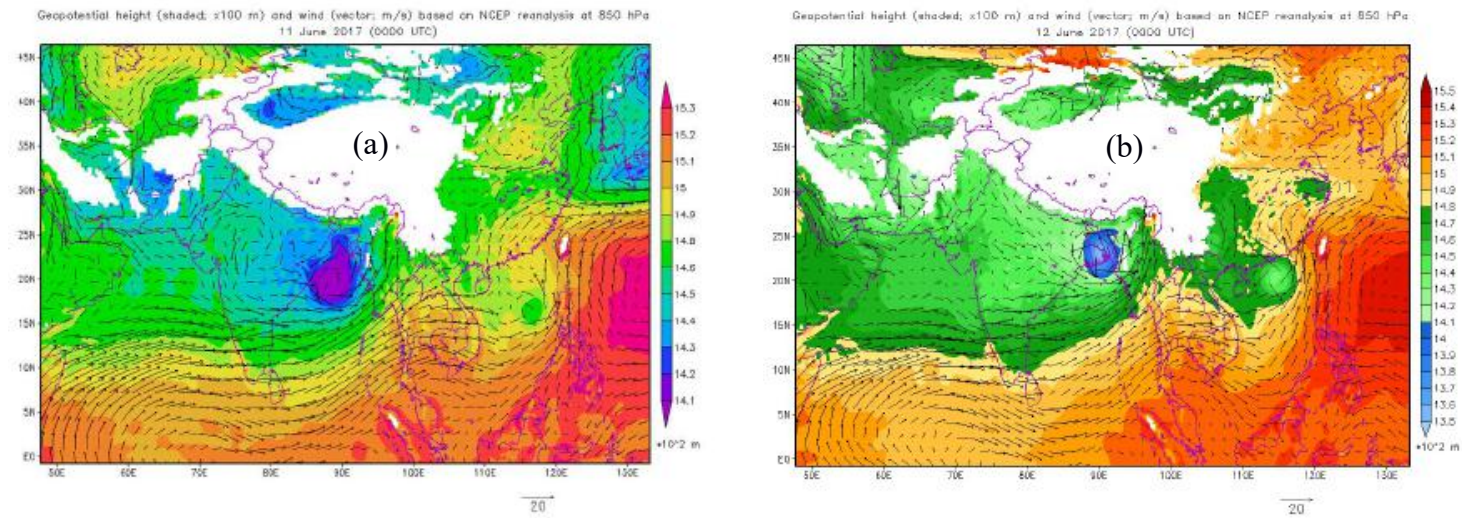

Figure 9: Large scale distribution of geopotential height and winds at $850 \mathrm{hPa}$ at $0000 \mathrm{UTC}$ on (a) 11 June and

(b) 12 June 2017

At $850 \mathrm{hPa}$ level, the distributions of geopotential height and winds at $0000 \mathrm{UTC}$ on 12 June 2017 over south Asia are shown in Figure 9b. The figure shows that the centre of low geopotential height is shifted over Bhola and adjoining area with minimum geopotential height $1340 \mathrm{~m}$ at the centre. The distribution patterns of geopotential height and wind are almost the same as on 11 June 2017. Relatively lower geopotential height of 1410 to $1420 \mathrm{~m}$ exists over northern India and northern Bangladesh. The maximum geopotential height from 1410 to $1440 \mathrm{~m}$ is found in the northern BoB and AS. A strong circulation pattern of wind is found in the central south to the north eastern part of Bangladesh, where the wind speed $>20 \mathrm{~ms}^{-1}$. There is strong southwesterly flow of winds from the Somalia coast passing through the AS, southern continental area of India and the BoB converging into the low geopotential centre. The wind speed has become stronger over Chittagong Hill Tracts. The winds of low speed are found in the northern side of India, Bangladesh and Myanmar.

Analysis of magnified chart of $850 \mathrm{hPa}$ at $0000 \mathrm{UTC}$ on 12 June 2017 indicates a well-defined depression over Bangladesh with a trough extended over Rangamati region and strong south-southeasterly wind flows over there. Strong winds of $20-30 \mathrm{~ms}^{-1}$ are also found over the BoB, which has been responsible for strong moisture 
influx over the depression area and has been responsible for very heavy rainfall, causing disastrous landslides in Chittagong Hill Tracts (Figure 10a). A narrow band of maximum wind speed of 25-30 ms ${ }^{-1}$ exists at $850 \mathrm{hPa}$ over Rangamati region as can be seen from Figure 10a. This strong wind at $850 \mathrm{hPa}$ level has created a strong wind shear at the surface, damaging significantly the structural properties and natural resources there. The minimum geopotential in the depression centre is about $1350 \mathrm{~m}$ at 0000 UTC on 12 June. Figure 10b, magnified chart of $850 \mathrm{hPa}$ at $0600 \mathrm{UTC}$ on 12 June 2017, shows that a micro low of geopotential height of $1350 \mathrm{~m}$ in the shape of comma is formed in the trough over Rangamati and adjoining area. This type of low is generally associated with disastrous weather event and it justifies the situation, which occurred in Rangamati region.
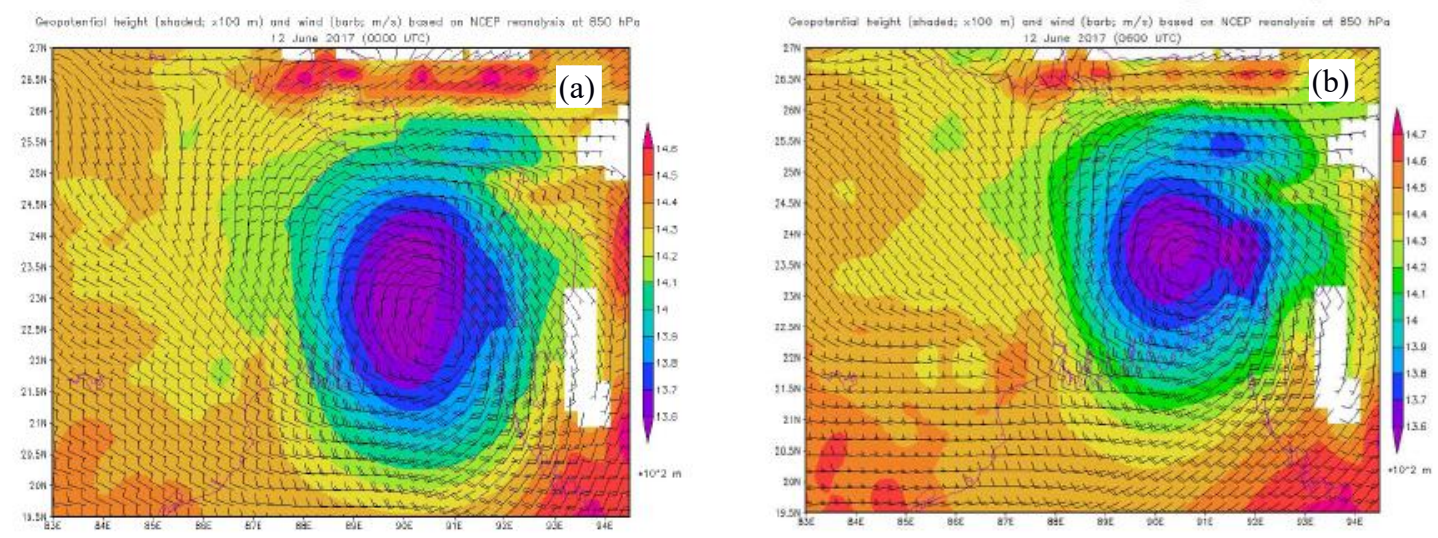

Figure 10: Magnified synoptic conditions at $850 \mathrm{hPa}$ of (a) 0000 and (b) 0600 UTC on 12 June 2017

At $500 \mathrm{hPa}$ level, the distributions of geopotential height and winds at $0000 \mathrm{UTC}$ on 11 and 12 June 2017 over Bangladesh and adjoining area are shown in Figures 11(a-b). The low in terms of geopotential height is found over northwest BoB at 0000 UTC on 11 June; the lower geopotential height is $5800-5850 \mathrm{~m}$ over the northwest Bay, having a trough towards southwest covering the Arabian Sea. Relatively lower geopotential height exists over India, AS and adjoining BoB (Figure 11a). The winds in the circulation over the $\mathrm{BoB}$ are weaker with 5 $\mathrm{ms}^{-1}$ but the winds are stronger (about $20 \mathrm{~ms}^{-1}$ ) and southwesterly in the southeastern coast of Bangladesh and southerly over Chittagong Hill Tracts. It is interesting to note that the cross-equatorial flow over the AS is absent at $500 \mathrm{hPa}$ but there is cross-equatorial flow over the BoB. There are two strong anticyclones; one over the Arabian region with extended ridge eastward up to Pakistan and the other over the Pacific Ocean east of the Philippines. A strong westerly trough is found over Uttar Pradesh and south of Nepal; this westerly trough is responsible for the intensification of the depression.
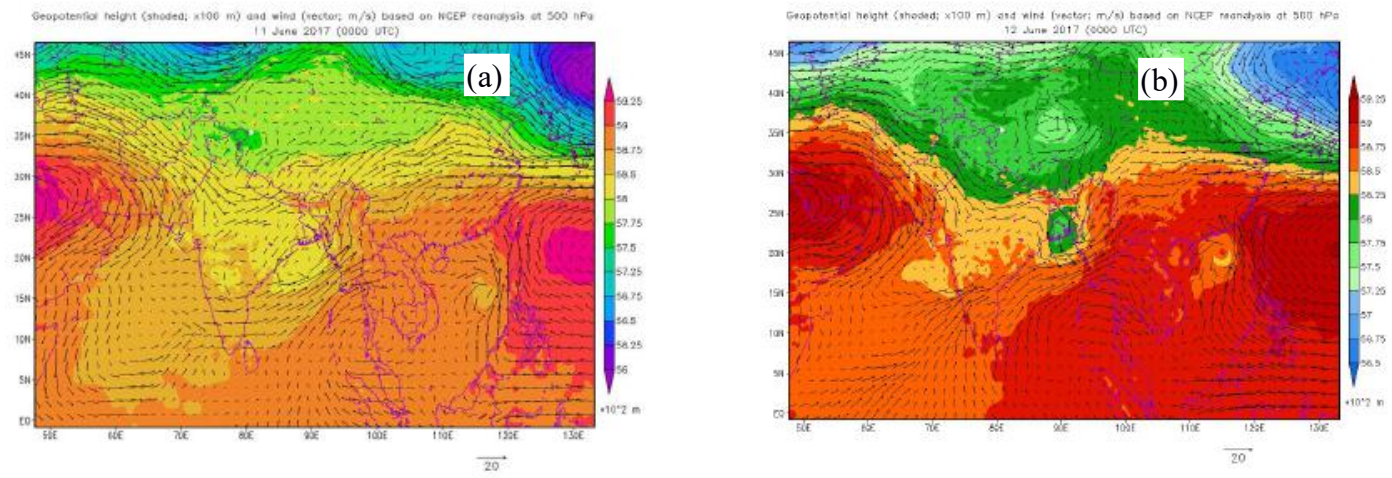

Figure 11: Large scale distribution of geopotential height and winds at $500 \mathrm{hPa}$ at $0000 \mathrm{UTC}$ on (a) 11 June and (b) 12 June 2017

On 12 June 2017, the low is found to move over Bangladesh with minimum geopotential height of about 5750m (Figure 11b). The winds are relatively stronger (about $20 \mathrm{~ms}^{-1}$ ) over the BoB and the eastern side of the depression in comparison with those on 11 June. The large-scale flow patterns are almost the same as on 11 June, having cross-equatorial flows both over the AS and the BoB. The westerly trough over Uttar Pradesh and Nepal has become more prominent and moved slightly eastward, indicating the northeast movement of the depression. 


\subsection{Large scale distribution of geopotential height and winds at $500 \mathrm{hPa}$}

The magnified synoptic conditions at $500 \mathrm{hPa}$ of 0000 UTC on 11-12 June 2017 are shown in Figures 12(a-b). On 11 June, the low in terms of geopotential exists over the northwest BoB, with a trough extended to northnorthwest Bangladesh; the minimum geopotential height at the centre of the depression is about $5820 \mathrm{~m}$. Southeasterly to easterly winds of $10 \mathrm{~ms}^{-1}$ exist over Bangladesh (Figure 12a). On 12 June at 0000 UTC, the depression has moved over Bangladesh with minimum geopotential height of $5780 \mathrm{~m}$ near the centre and a narrow strong coma-like trough is extended from the eastern side of the depression towards south over Chittagong Hill Tracts (Figure 12b). Strong circulation is found over the country with stronger southerly winds of 20-25 $\mathrm{ms}^{-1}$ over the eastern side of the depression. The extended narrow strong trough and the stronger southerly winds over the Chittagong Hill Tracts can be attributed to the ruinous damages in Rangamati and adjoining areas.
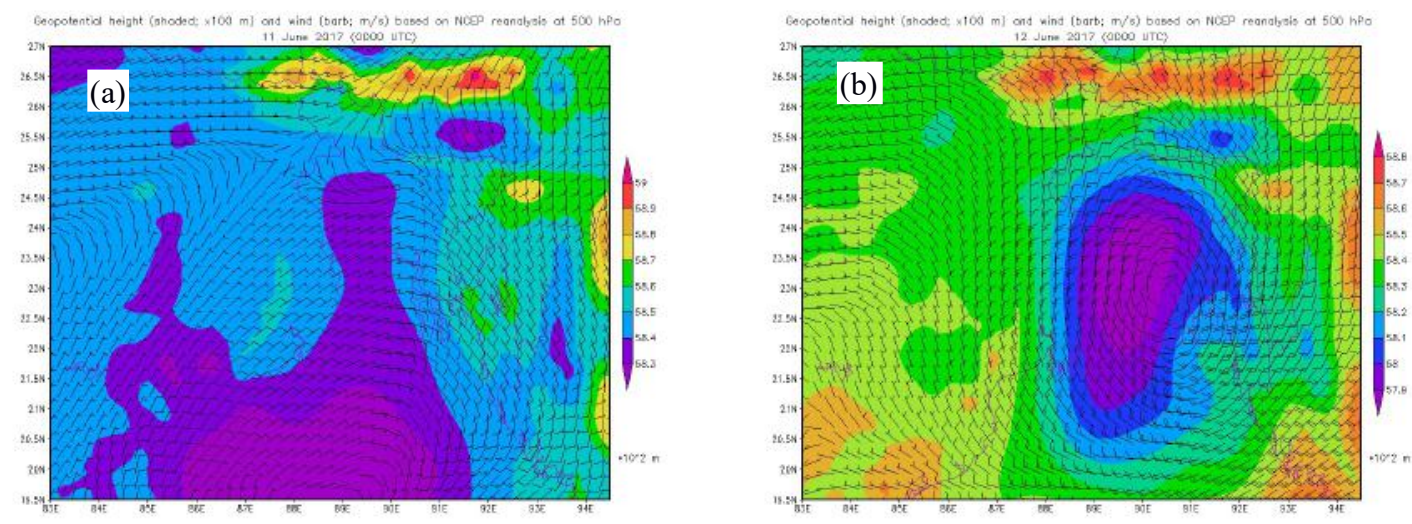

Figures 12: Magnified synoptic conditions at $500 \mathrm{hPa}$ of $0000 \mathrm{UTC}$ on (a) 11 June and (b) 12 June 2017
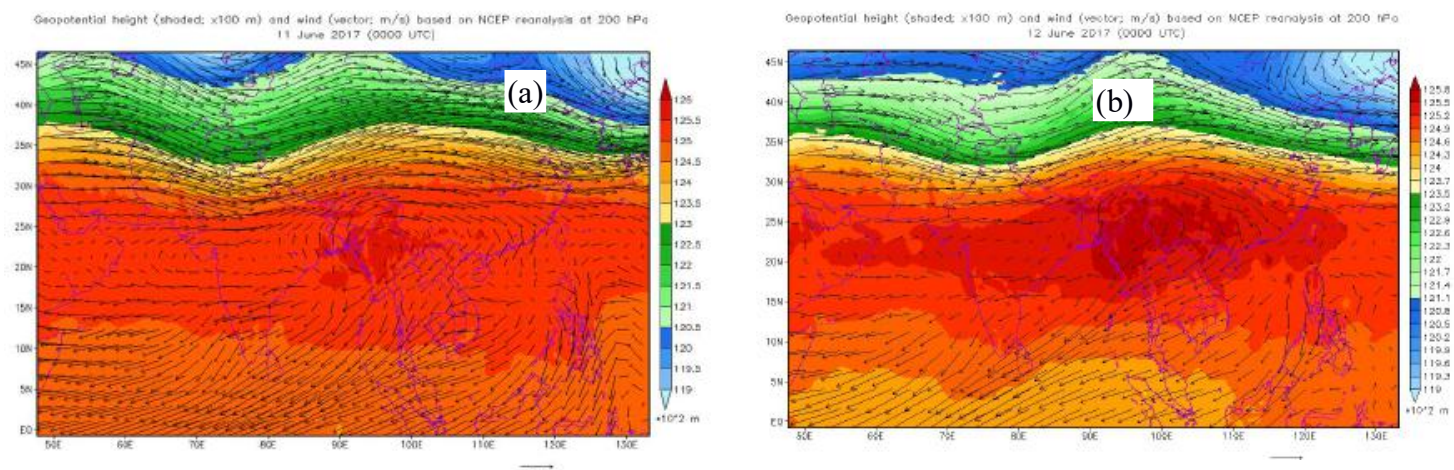

Figure 13: Large scale distribution of geopotential height and winds at $200 \mathrm{hPa}$ at $0000 \mathrm{UTC}$ on (a) $11 \mathrm{June}$ and (b) 12 June 2017

\subsection{Large scale distribution of geopotential height and winds at $200 \mathrm{hPa}$}

At $200 \mathrm{hPa}$ level, the distributions of geopotential height and winds at 0000 UTC on 11 June 2017 over Bangladesh and adjoining area is shown in Figure 13(a). A well-defined westerly trough exists over northern India and an anticyclone over Myanmar and adjoining eastern Bangladesh, having southerly wind diverging towards northeast over Bangladesh. This southerly wind diverging towards northeast over Bangladesh has acted as the steering wind for the depression to move north-northeasterly direction. In the northern side of Pakistan, India, Nepal, Bangladesh and Bhutan, the strong westerly winds of speed $>20 \mathrm{~ms}^{-1}$ are found to prevail. The whole south $\mathrm{BoB}$ and the Arabian Sea are characterized by easterly winds. At that time, the maximum geopotential height $12,550 \mathrm{~m}$ to $12,600 \mathrm{~m}$ is found in the anticyclone over Myanmar.

On 12 June, the large-scale circulation pattern at $200 \mathrm{hPa}$ level is almost the same as that on 11 June 2017 (Figure 13b). The anticyclone has become more prominent over Myanmar, adjoining Bangladesh and China with stronger southerly steering wind of $20 \mathrm{~ms}^{-1}$ from south to Sylhet region over Bangladesh, the wind guided the depression to move in a northeasterly direction. The maximum geopotential height of $12,580 \mathrm{~m}$ is found in the anticyclone over Myanmar. 


\section{CONCLUSIONS}

On the basis of the present study, the following conclusions can be drawn:

i. The disastrous event is a strong monsoon depression in the early period of southwest monsoon 2017, responsible for very heavy rainfall in the southeastern Bangladesh with $343 \mathrm{~mm}$ rainfall at Rangamati in 24 hours on 12 June 2017 and massive landslides in three districts such as Rangamati, Bandarban and Chittagong.

ii. The central pressure of the well-marked low in the Northwest BoB has minimum pressure of about $995 \mathrm{hPa}$ on 11 June 2017. There is a belt of low pressure system from Somalia coast extending through southern Pakistan, and India up to east central BoB and adjoining Bangladesh. In the south and east (Eastern Asia) of the low-pressure belt, the sea level pressure ranges from $1004 \mathrm{hPa}$ over the Arabian Sea and BoB to more than $1010 \mathrm{hPa}$ over the South Indian Ocean. The range of 1010 to $1021 \mathrm{hPa}$ pressure is found to exist in Tibetan Plateau and adjoining areas. The wind speed is calculated from the pressure distribution and is $24.23 \mathrm{~ms}^{-1}$, which is at par with the observed one.

iii. The existence of the low-pressure belt over Somalia-Pakistan-India-Bangladesh and North BoB is responsible to bring strong southwesterly winds over the Arabian and the BoB, intensifying the southwest monsoon over South Asia and converging the winds into the well-marked low as well as over the lowpressure belt. The well-marked low has intensified into a depression at 0000 UTC on 12 June 2017 and moved subsequently in northeasterly direction over Bangladesh.

iv. At $950 \mathrm{hPa}$, the depression centre has low geopotential height of $380 \mathrm{~m}$ over Cumilla and adjoining area and a separate micro-cell of low geopotential height formed in the extended trough over Rangamati region and a separate micro-cell of low geopotential height formed in the extended trough over Rangamati region at 0600 UTC on 12 June 2017. There was intense circulation over eastern Cumilla and Rangamati with stronger wind speed than that $10 \mathrm{~m}$ level. The winds are found to advect into the centre of the depression from large continental and ocean areas; the micro low becomes more prominent with narrow trough extended to north Rangamati at 1200 UTC.

v. On 12 June at 0000 UTC, strong winds of $20-30 \mathrm{~ms}^{-1}$ are found at $850 \mathrm{hPa}$ level over the BoB, which has been responsible for strong moisture influx over the depression area, causing very heavy rainfall as well as disastrous landslides in Chittagong Hill Tracts. There is a narrow band of maximum wind speed of 25-30 $\mathrm{ms}^{-1}$ at $850 \mathrm{hPa}$ over Rangamati region, creating a strong wind shear at the surface and damaging significantly the structural properties and natural resources there.

vi. At 0600 UTC on 12 June 2017, there is a micro low of geopotential height of $1350 \mathrm{~m}$ in the shape of a comma at $850 \mathrm{hPa}$ in the trough over Rangamati and adjoining area. This type of low is generally associated with disastrous weather event and it justifies the situation, which has occurred in Rangamati region.

vii. The depression is to extend vertically upwards up to $500 \mathrm{hPa}$ at $0000 \mathrm{UTC}$ on 11 June with lower geopotential height of 5800-5850 m over the northwest Bay, having a trough towards southwest covering the Arabian Sea. Relatively lower geopotential height was found to exist over India, Arabian Sea and adjoining BoB.

viii. The winds in the circulation over the BoB are weaker with $5 \mathrm{~ms}^{-1}$ at $500 \mathrm{hPa}$ at $0000 \mathrm{UTC}$ on $11 \mathrm{June}$ but the winds are stronger (about $20 \mathrm{~ms}^{-1}$ ) and southwesterly in the southeastern coast of Bangladesh and southerly over Chittagong Hill Tracts. The cross-equatorial flow was over the Arabian Sea is absent at 500 $\mathrm{hPa}$ but there was cross-equatorial flow over the BoB. Two strong anticyclones are found: one over the Arabian region with extended ridge eastward up to Pakistan and the other over the Pacific Ocean east of the Philippines. A strong westerly trough is found at $500 \mathrm{hPa}$ over Uttar Pradesh and south of Nepal; this westerly trough is responsible for the intensification of the depression.

ix. A narrow strong trough of minimum geopotential height of $5780 \mathrm{~m}$ is extended from the eastern side of the depression towards south over Chittagong Hill Tracts with stronger southerly winds of $20-25 \mathrm{~ms}^{-1}$ over the eastern side of the depression. The extended narrow strong coma-shaped trough and the stronger southerly winds over the Chittagong Hill Tracts could be attributed to the ruinous damages in Rangamati and adjoining areas.

x. A well-defined westerly trough is present at $200 \mathrm{hPa}$ over northern India and an anticyclone over Myanmar and adjoining eastern Bangladesh, having southerly wind diverging towards northeast over Bangladesh. This southerly wind diverging towards northeast over Bangladesh guided the depression as the steering wind to move north-northeasterly direction.

\section{REFERENCES}

Ahmed, R., and Karmakar S., 1993. Arrival and withdrawal dates of the summer monsoon in Bangladesh, International Journal of Climatology, Royal Met. Soc., 13, 727-740. 
Ananthakrishnan, R., Srinivasan V., Ramakrishna A.R., and Jambunathan R., 1968. Synoptic features associated with onset of southwest monsoon over Kerala, IMD Forecasting Manual, Report IV-18.2.

Ananthakrishnan, R., and Soman M.K., 1988. The onset of southwest monsoon over Kerala (1901-1980), International Journal of Climatology, 8, 283-296.

Ananthakrishnan, R., and Soman M.K., 1989. The onset of southwest monsoon over Kerala for the period (1870-1900), International Journal of Climatology, 8, 321-322.

BMD, 2017. Rainfall for last 24 hours till 06 AM on 13 June 2017.

Chowdhury, M. H. K., and Karmakar S., 1980a. Some aspects of energetic of the troposphere over the Arabian Sea with advancement of south-west monsoon, FGGE Operations Report: Results of Summer Monex Field Phase Research, 9, Part-A, 81-91.

Chowdhury, M. H. K., and Karmakar S., 1980b. Diagnostic study on some aspects of energetics and structural features of the troposphere over the Arabian Sea with the advancement of SW-Monsoon, FGGE Operations Report: Results of Summer Monex Field Phase Research, 9, Part-B, 212-240.

Das Mohan K., Islam A. K. M. S., Khan Md. J. U., and Karmakar S, 2017. Numerical Simulation of FlashFlood-Producing Heavy rainfall of 16 April 2016 in NE Regions of Bangladesh. Vayu Mandal, 43(2), 97-108.

Findlater, J., 1969. A major low-level air current near the Indian Ocean during the northern summer, Quarterly Journal of the Royal Meteorological Society, 95, 362-380.

Hsu, H.H., Terng C.T., and Chen C.T., 1999. Evolution of large-scale circulation and circulation and heating during the first transition of Asian summer monsoon, Monthly Weather Review, 12, 793-810.

Joseph, P.V., and Raman P.L., 1966. Existence of Low-Level Westerly Jet Stream over Peninsular India during July, Indian Journal of Meteorology Hydrology and Geophysics, 17, 407-410.

Koteswaram, P., 1958. The easterly jet stream in the tropics, Tellus, 10, 43-57.

Krishnamurti, T.N., and Ramanathan Y., 1982. Sensitivity of the monsoon onset to the differential heating, Journal of the Atmospheric Sciences, 39, 1290-1306.

Li, C., and Yanai M., 1996. The onset and interannual variability of the Asian summer monsoon in relation to land-sea thermal contrast. Journal of Climate, 9, 358-375.

Mishra, D. K., and Gupta G. R., 1976. Estimation of max wind speed in tropical cyclone occurring in India Seas, Indian J Met. Hydro. \& Geophys. 27(3), 285-290.

Mohanty, U.C., Dube S.K., and Singh, M.P., 1983. A study of heat and moisture budget over the Arabian Sea and their role in the onset and maintenance of summer monsoon, Journal of the Meteorological Society of Japan, 61, 208-221.

Murakami,T., and Ding Y.H., 1982. Wind and temperature changes over Eurasia during the early summer of 1979, Journal of the Meteorological Society of Japan, 60, 183-196.

Pearce, R.P., and Mohanty U.C., 1984. Onsets of the Asian summer monsoon (1979-1982), Journal of the Atmospheric Sciences, 41, 1622-1639.

Raju, P.V.S., Mohanty U.C., and Bhatla R., 2005. Onset characteristics of the southwest monsoon over India, International journal of Climatology, 25, 167-182.

Rao, G.V., and Aksakal A., 1994. Characteristics of convection over the Arabian Sea during a period of monsoon onset, Journal of the Atmospheric Sciences, 33, 235-258.

Reliefweb, 2017. Landslides Situation in Southeast Bangladesh, Report from NIRAPAD, Published on 14 Jun 2017, https://reliefweb.int/report/bangladesh/landslides-situation-southeast-bangladesh-june-2017

Soman, M.K., and Krishnakumar K., 1993. Space-time evolution of meteorological features associated with the onset of Indian summer monsoon, Monthly Weather Review, 121, 1177-1194.

(C) 2020 The Authors. Journal of Engineering Science published by Faculty of Civil Engineering, Khulna University of Engineering \& Technology. This is an open access article under the terms of the Creative Commons AttributionNonCommercial-NoDerivatives License, which permits use and distribution in any medium, provided the original work is properly cited, the use is non-commercial and no modifications or adaptations are made. 